\title{
OTL Detection with Single Diallelic Markers in a Paternal Half-sib Family
}

\author{
Kenji TOGASHI, Tsutomu YOSHIZAWA ${ }^{1)}$, Keijiro NIRASAWA ${ }^{1)}$, \\ Tadayoshi MITSUHASHI ${ }^{*}$, Naoyuki YAMAMOTO \\ and Osamu SASAKI \\ Hokkaido National Agricultural Experiment Station, \\ Toyohira-ku, Sapporo-shi 062-8555 \\ 1) National Livestock Breeding Center, Nishigo-mura, \\ Fukushima-ken 961-8061
}

(Received April 27, 1998)

\begin{abstract}
A certain marker allele may co-segregate with a favorable QTL allele in one half-sib family and with an unfavorable QTL allele in a different half-sib family. On the other hand, an elite proven sire forms a large family in dairy cattle population. Diallelic markers of $\mathrm{M}$ and $\mathrm{m}$ are assumed to be segregating in such a family consisting of an elite proven sire (grandsire), his halfsib sons and his granddaughters. Simple best linear unbiased prediction (BLUP) procedure of sire model was applied treating the expected number of a QTL allele as a covariate in order to detect a QTL segregating in the family. The design was named combined design from the standpoint that genotyping was conducted in three generations in order not to waste the sires genotyped $\mathrm{Mm}$ which were uninformative in granddaughter design with single dialellic markers. Daughters records from sires of $(\mathrm{MM}, \mathrm{mm}),(\mathrm{Mm})$, and $(\mathrm{MM}, \mathrm{Mm}, \mathrm{mm})$ were treated as granddaughter, daughter and combined designs, respectively. The size of type 1 error probability on the test of the presence of a QTL was compared among daughter, granddaughter and combined designs. Combined design appeared to have the least type 1 error probability in hierarchical pedigree examples. The combined design basing a large elite proven sire family would serve as an initial glance for further detailed QTL deliberation, especially in the case of diallelic markers.
\end{abstract}

Anim. Sci. Technol. (Jpn.) 69 (10) : 903-910, 1998

Key words : Elite proven sire, QTL detection, Combined design, Half-sib family

Togashi et al. ${ }^{16)}$ has shown that QTL detection can be smoothly realized by using sires generated from crossing two genetically different pedigrees in paternal half-sib populations. On the other hand, Georges et al. ${ }^{3)}$, Spelman et $a l .^{15)}$, Ron et al. ${ }^{14)}$, and Vilkki et al. ${ }^{17)}$ have suggested that QTL allele was segregating even under the ongoing progeny testing in dairy cattle population. Thus, once a grandsire which is heterozygous at one QTL is proved as an elite proven sire, the grandsire would make a large family consisting of his half-sib sons and granddaughters. It indicates that there should be some appropriate and preliminary procedures for QTL detection making the best use of such a large grandsire family before advancing a detailed QTL analysis ${ }^{4,8-10,12)}$ in large and complex populations. Further, such detailed procedures are developed under the situation without marker information. From this point of view, Weller et al. ${ }^{18)}$ proposed a granddaughter design and

\footnotetext{
* Present address : National Institute of Animal Industry, Tsukuba Norin Kenkyu Danchi, Ibaraki-ken 305-0901
} 
daughter design under the condition that transmission of marker allele from a grandsire to his sons or from a sire to his daughters was unequivocally determined. This assumption would be ensured as the number of marker allele is getting more. However, in a case of diallelic markers, the assumption would be hard to ensure. In a daughter design or granddaughter design by Weller et al. ${ }^{18)}$, genotyping is conducted separately in two generations of an elite proven sire and his half-sib sons (granddaughter design) and a sire and his daughters (daughter design). On the other hand, genotyping can be conducted within an elite proven sire family throughout three generations of grandsire, his half-sib sons and granddaughters. It would help to estimate the transmission of a QTL allele of the elite proven sire to his descendants such as his half-sib sons and granddaughters. And it would also help to estimate sire's linkage phase of the marked QTL and marker locus more accurately than without markers in sire's previous generation. Its design is named combined design. In particular, a sire genotyped $\mathrm{Mm}$ in the granddaughter design by Weller et al. ${ }^{18)}$ becomes uninformative in single diallelic markers. However, association between the marked QTL and marker can be analyzed even in such a sire by extending genotyping to his daughters.

Linear regression methods have been applied in to QTL mapping ${ }^{5,6,11}$, since it is fast and easy to screen the entire genome. A linear regression analysis has been conducted for each paternal family treating the probability for progeny to inherit the two QTL alleles of its sire as a covariate. Expected number of the alternative QTL alleles in its locus is denoted as a covariate here, which ends up with the genotypic value of the QTL by multiplying the expected number and regression coefficient assuming no dominance. Thus, the QTL value and other additive effect not linked to the QTL in granddaughter's record from an elite proven sire can be estimated by BLUP procedure ${ }^{7)}$.
The objective of this paper is to propose a preliminary procedure for QTL detection with single diallelic markers by gathering markers in three generations of a grandsire, his sons and his granddaughters in a large grandsire family in order not to waste sires genotyped $\mathrm{Mm}$ and so as to enhance the estimation of linkage phase of sires.

\section{Materials and Methods}

\section{Genetic model}

A grandsire or elite proven sire is assumed double heterozygous for the marked QTL $(\mathrm{Q} / \mathrm{q})$ and single marker locus $(\mathrm{M} / \mathrm{m})$ with the linkage phase of $\mathrm{M}-\mathrm{Q} / \mathrm{m}-\mathrm{q}$. Two alleles are assumed in both the marked QTL and marker locus. Thus a grandsire has one of four possible marker-QTL haplotypes with the recombination rate of $r$, i.e. $M-Q, M-q, m-Q$ and $m-$ $\mathrm{q}$ with the frequency $(1-\mathrm{r}) / 2, \mathrm{r} / 2, \mathrm{r} / 2$ and $(1-$ r) $/ 2$, respectively. The generation of grandsire and grandam is assumed to be at HardyWeinberg equilibrium with respect to one marked QTL, marker locus and loci for polygenes. Genotyping is conducted in three generations of a grandsire, his sons and his granddaughters. As granddam has no information on the QTL and marker locus, a sire genotyped $\mathrm{Mm}$ has one of four possible marker-QTL genotypes, i.e. $\mathrm{M}-\mathrm{Q} / \mathrm{m}-\mathrm{Q}, \mathrm{M}-\mathrm{Q} / \mathrm{m}-\mathrm{q}, \mathrm{M}-\mathrm{q} /$ $\mathrm{m}-\mathrm{Q}$ and $\mathrm{M}-\mathrm{q} / \mathrm{m}-\mathrm{q}$ with the frequency of $\mathrm{p} / 2,(1-\mathrm{r}) / 2, \mathrm{r} / 2$ and $(1-\mathrm{p}) / 2$, respectively, denoting $\mathrm{p}$ as the frequency of $\mathrm{Q}$ (Table 1 ). In the same way, a sire genotyped MM has one of three possible marker-QTL genotypes, i.e. $\mathrm{M}-$ $\mathrm{Q} / \mathrm{M}-\mathrm{Q}, \mathrm{M}-\mathrm{Q} / \mathrm{M}-\mathrm{q}$ and $\mathrm{M}-\mathrm{q} / \mathrm{M}-\mathrm{q}$ with the frequency of $(1-r) p,(1-r)(1-p)+r p$ and $r(1-p)$, respectively, A sire genotyped $\mathrm{mm}$ has one of three possible marker-QTL genotypes, i.e. $\mathrm{m}-\mathrm{Q} / \mathrm{m}-\mathrm{Q}, \mathrm{m}-\mathrm{Q} / \mathrm{m}-\mathrm{q}$ and $\mathrm{m}-\mathrm{q} /$ $\mathrm{m}-\mathrm{q}$ with the frequency of $\mathrm{rp}, \mathrm{r}(1-\mathrm{p})+(1-\mathbf{r}) \mathrm{p}$ and $(1-r)(1-p)$, respectively. A sire generates gamates in the same way as a grandsire does allowing for the same recombination rate. Sire's mate has no information on the QTL and 
marker. As a result, expected number of the allele $\mathrm{Q}$ in the QTL in a record of an elite sire's granddaughter can be given under the condition that marker information is available on the grandsire's half-sib sons and granddaughters. For instance, a sire whose linkage phase is $\mathrm{M}-\mathrm{Q} / \mathrm{m}-\mathrm{q}$ generates marker-QTL haplotype of $\mathrm{M}-\mathrm{Q}, \mathrm{m}-\mathrm{q}, \mathrm{M}-\mathrm{q}$ and $\mathrm{m}-\mathrm{Q}$ with the frequency of $(1-r) / 2,(1-r) / 2, r / 2$ and $r / 2$, respectively. As dam has no data on its marker, the number of $Q$ in granddaughters genotyped $M M, M m$ and $m m$ from the sire $(M-Q / m-q)$ is $p+1-r, p+1 / 2$ and $p+r$, respectively (Table 2). The expected number of $Q$ in a granddaughter is shown in Table 2 corresponding to other linkage phase of sire with the same marker genotype $(\mathrm{Mm})$. As a result, the expected number of $Q$ in a granddaughter $(M M)$ from a sire $(\mathrm{Mm})$ amounts to $(\mathrm{p} / 2)^{*}(\mathrm{p}+1)+(1-$ r) $/ 2^{*}(\mathbf{p}+1-\mathbf{r})+\mathrm{r} / 2^{*}(\mathbf{p}+\mathbf{r})+(1-\mathrm{p}) / 2^{*} \mathrm{p}$. In the same way, the expected number of $Q$ in a granddaughter $\mathrm{Mm}$ and $\mathrm{mm}$ from a sire $\mathrm{Mm}$ is given as $3 p / 2+1 / 4$ and $\left(3 p+2 r-2 r^{2}\right) / 2$, respectively. The expected number of $Q$ in a granddaughter is shown in Table 3 corresponding to all the marker genotypes of sire and granddaughter.

\section{Statistical model}

Granddaughter's record is represented by sire model ${ }^{\text {? }}$,

Table 1. Derivation of sires genotyped $\mathrm{Mm}$

\begin{tabular}{|c|c|c|c|c|}
\hline & \multicolumn{4}{|c|}{ Gamate from grandsire } \\
\hline & $\begin{array}{c}M-Q \\
((1-r) / 2)\end{array}$ & $\underset{(\mathrm{r} / 2)}{\mathrm{M}-\mathrm{q}}$ & $\underset{(\mathrm{r} / 2)}{\mathrm{m}-\mathrm{Q}}$ & $\underset{((1-r) / 2)}{m-q}$ \\
\hline Gamate & $\underset{(p)}{m-Q}$ & $\begin{array}{c}m-Q \\
(p)\end{array}$ & $\underset{(p)}{M-Q}$ & $\underset{(p)}{M-Q}$ \\
\hline granddam & $\begin{array}{l}m-q \\
(1-p)\end{array}$ & $\begin{array}{l}m-q \\
(1-p)\end{array}$ & $\begin{array}{l}M-q \\
(I-p)\end{array}$ & $\begin{array}{l}M-q \\
(1-p)\end{array}$ \\
\hline
\end{tabular}

Remarks 1 : Figures within brackets stand for the frequency of each gamate.

$2: r$ is recombination rate.

$3: p$ is the frequency of $Q$.

Table 2. Expected number of QTL allele (Q) in a record of granddaughter from a sire genotyped $\mathrm{Mm}$

\begin{tabular}{clllc}
\hline \hline \multirow{2}{*}{\begin{tabular}{c} 
Marker genetypes $\begin{array}{c}\text { of } \\
\text { granddaughter }\end{array}$ \\
\cline { 2 - 5 }
\end{tabular}} & $\begin{array}{c}\mathrm{M}-\mathrm{Q} \\
\mathrm{m}-\mathrm{q}\end{array}$ & $\begin{array}{c}\mathrm{M}-\mathrm{Q} \\
/ \mathrm{m}-\mathrm{Q}\end{array}$ & $\begin{array}{l}\mathrm{M}-\mathrm{q} \\
/ \mathrm{m}-\mathrm{Q}\end{array}$ & $\begin{array}{c}\mathrm{M}-\mathrm{q} \\
/ \mathrm{m}-\mathrm{q}\end{array}$ \\
\hline $\mathrm{MM}$ & $\mathrm{p}+1-\mathrm{r}$ & $\mathrm{p}+1$ & $\mathrm{p}+\mathrm{r}$ & $\mathrm{p}$ \\
$\mathrm{Mm}$ & $\mathrm{p}+1 / 2$ & $\mathrm{p}+1$ & $\mathrm{p}+1 / 2$ & $\mathrm{p}$ \\
$\mathrm{mm}$ & $\mathrm{p}+\mathrm{r}$ & $\mathrm{p}+1$ & $\mathrm{p}+1-\mathrm{r}$ & $\mathrm{p}$ \\
\hline
\end{tabular}

Table 3. Expected number of QTL allele (Q) in a record of granddaughter corresponding to marker genotypes of sire and granddaughter

\begin{tabular}{cccc}
\hline \hline $\begin{array}{c}\text { Granddaughter's } \\
\text { genotypes }\end{array}$ & \multicolumn{1}{c}{ Sire's genotypes } \\
\cline { 2 - 4 } & \multicolumn{1}{c}{$\mathrm{Mm}$} & $\mathrm{MM}$ & $\mathrm{mm}$ \\
\hline $\mathrm{MM}$ & $\left(2 \mathrm{r}^{2}-2 \mathrm{r}+3 \mathrm{p}+1\right) / 2$ & $(3 \mathrm{p}+1-\mathrm{r}) / 2$ & $(\mathrm{r}+3 \mathrm{p}) / 2$ \\
$\mathrm{Mm}$ & $3 \mathrm{p} / 2+1 / 4$ & $(3 \mathrm{p}+1-\mathrm{r}) / 2$ & $(\mathrm{r}+3 \mathrm{p}) / 2$ \\
$\mathrm{~mm}$ & $\left(3 \mathrm{p}+2 \mathrm{r}-2 \mathrm{r}^{2}\right) / 2$ & $(3 \mathrm{p}+1-\mathrm{r}) / 2$ & $(\mathrm{r}+3 \mathrm{p}) / 2$ \\
\hline
\end{tabular}




$$
\mathrm{Y}_{\mathrm{ij}}=\mu+\mathrm{bx}+\mathrm{s}_{\mathrm{i}}+\mathrm{e}_{\mathrm{ij}}
$$

where $Y_{i j}$ is the phenotypic value of jth daughter from ith sire ; $\mu$ is the overall mean ; $\mathrm{x}$ is the expected number of $Q ; b$ is regression coefficient or the average effect of the gene substitution ${ }^{2)} ; \mathrm{s}_{\mathrm{i}}$ is a half of the additive genetic effect of sire $i$ with the mean zero and $\sigma s^{2}$ and $\mathrm{e}_{\mathrm{ij}}$ is a normally distributed residual variable with the mean zero and $\sigma e^{2}$. Only one chromosome segment locating the marked QTL and marker locus is considered for the purpose of comparing daughter, granddaughter and combined designs. Each situation for QTL detection is determined by recombination rate $(5,10$, $20 \%$ ), the QTL variance in terms of the total additive genetic variance $(10,20 \%)$, paternal half-sib family size $(50,100)$ and the number of grandsire $(1,2)$. Two grandsires with the same marker-QTL linkage phase are assumed unrelated each other. Relationships among sires are given only from male side, i.e. female side is assumed to be non-related. The number of half-sib sons per grandsire is set at 80 and 40 for 1 and 2 grandsires, respectively. Data from sires or an elite sire's sons genotyped MM and $\mathrm{mm}$ are adopted in granddaughter design, since transmission of $\mathrm{Q}$ or $\mathrm{q}$ in a grandsire to his son cannot be determined unequivocally in sires genotyped $\mathrm{Mm}$ in a case of single diallelic markers. Data from sires $\mathrm{Mm}$ are adopted in daughter design. Data from all sires of $\mathrm{MM}$, $\mathrm{Mm}$ and $\mathrm{mm}$ are adopted in combined design. Thus combined design uses all sires data, since expected number of $Q$ can be given in the records of all the granddaughters by gathering marker information for a grandsire, his halfsib sons and granddaughters. The difference of reduction in sum of squares between fitting and excluding the terms of regression is compared to the residual variance with an $F$ ratio. The extent on the presence of a QTL is described as the degree of type 1 error probability. Heritability of the trait is assumed 0.3 . The frequency of alternative QTL alleles in the generations of grandsire, grandam and dam is assumed 0.5. Simulation is replicated 500 times for each situation.

\section{Results and Discussion}

The size of type 1 error probability and $F$ values for 50 daughters per sire are shown in Tables 4 and 5, respectively. The size of type 1 error probability in combined design was slightly smaller than that of daughter design in all situations. The error probability in granddaughter design was larger than those of daughter and combined designs. This tendency was relatively noticeable in the case of 1 grandsire compared to the case of 2 grandsires. The above results applied to the case of 100 daughters per sire as well. The trend of $F$ values endorsed that of type 1 error probability. Weller et al. ${ }^{18\rangle}$ pointed out that the power to detect a QTL is higher in granddaughter design than in daughter design under the condition that transmission of marker allele from a grandsire to his sons or from a sire to his daughters was unequivocally determined. Single diallelic marker is dealt with in this paper, in which sire's informative marker genotypes are limited to $\mathrm{MM}$ and $\mathrm{mm}$ in granddaughter design. That has resulted in waste of half the number of sires per grandsire and led to low power in detecting a QTL. In other words, granddaughter design with single diallelic markers would be the worst case scenario. Marker information in sire's previous generation is not used in daughter design by Weller et al. ${ }^{18)}$. On the other hand, inclusion of the grandsire's marker information helps to estimate the extent of heterozygosity of the marked QTL of the sire concerned. That is, daughter design adopted here is taking account of previous generation information. Thus, daughter design adopted here has more power than the one without grandsire information. Theoretically a sire genotyped $\mathrm{Mm}$ becomes uninformative in granddaughter design with single diallelic markers. However, daughter's marker information is collected 
QTL Detection in a Paternal Half-sib Family

Table 4. Type I error probability for the test of presence of a QTL (\%)

\begin{tabular}{|c|c|c|c|c|c|c|c|c|}
\hline \multicolumn{3}{|c|}{ Factor } & \multicolumn{6}{|c|}{ Number of grandsire } \\
\hline \multirow{3}{*}{$\begin{array}{l}\text { Recom- } \\
\text { bination } \\
\text { rate }(\%)\end{array}$} & \multirow{3}{*}{$\begin{array}{c}\text { Family } \\
\text { size }\end{array}$} & \multirow[b]{3}{*}{$V(Q T L) / V(G)$} & \multirow{2}{*}{\multicolumn{3}{|c|}{$\begin{array}{c}1 \\
\text { Designs }\end{array}$}} & \multirow{2}{*}{\multicolumn{3}{|c|}{$\begin{array}{c}2 \\
\text { Designs }\end{array}$}} \\
\hline & & & & & & & & \\
\hline & & & Daughter & Granddaughter & Combined & Daughter & Granddaughter & Combined \\
\hline 5 & 50 & 0.1 & 8.9 & 33.3 & 6.2 & 9.0 & 19. 4 & 3.8 \\
\hline 5 & 50 & 0.2 & 1.9 & 11.6 & 0.6 & 1.9 & 5.6 & 0.3 \\
\hline 10 & 50 & 0.1 & 15.7 & 39.4 & 13. 4 & 16.3 & 18.6 & 6.1 \\
\hline 10 & 50 & 0.2 & 5.9 & 16.8 & 2.5 & 6.3 & 6.0 & 0.8 \\
\hline 20 & 50 & 0.1 & 35.5 & 54.2 & 33.6 & 33.2 & 38.9 & 25.6 \\
\hline 20 & 50 & 0.2 & 24.6 & 33.9 & 17.4 & 24.9 & 27.5 & 10.8 \\
\hline
\end{tabular}

Table 5. F values for the test of presence of a QTL

\begin{tabular}{|c|c|c|c|c|c|c|c|c|}
\hline \multicolumn{3}{|c|}{ Factor } & \multicolumn{6}{|c|}{ Number of grandsire } \\
\hline \multirow{2}{*}{$\begin{array}{l}\text { Recom- } \\
\text { bination } \\
\text { rate }(\%)\end{array}$} & \multirow{2}{*}{$\underset{\text { size }}{\text { Family }}$} & \multirow[b]{2}{*}{$\mathrm{V}(\mathrm{QTL}) / \mathrm{V}(\mathrm{G})$} & \multicolumn{3}{|c|}{$\begin{array}{c}1 \\
\text { Designs }\end{array}$} & \multicolumn{3}{|c|}{$\begin{array}{c}2 \\
\text { Designs } \\
\end{array}$} \\
\hline & & & Daughter. & Granddaughter & Combined & Daughter & Granddaughter & Combined \\
\hline 5 & 50 & 0.1 & 2.88 & .93 & 3.49 & 2.87 & 1.68 & 4. 31 \\
\hline 5 & 50 & 0.2 & 5.53 & 2.46 & 7.66 & 5.47 & 3. 64 & 8.90 \\
\hline 10 & 50 & 0.1 & 1.99 & .72 & 2.24 & 1.94 & 1.75 & 3. 49 \\
\hline 10 & 50 & 0.2 & 3.58 & 1.90 & 5.01 & 3.46 & 3. 52 & 6.95 \\
\hline 20 & 50 & 0.1 & .85 & .37 & .92 & .94 & .74 & 1. 29 \\
\hline 20 & 50 & 0.2 & 1. 34 & .91 & 1. 84 & 1.33 & 1.53 & 2.58 \\
\hline
\end{tabular}

even from such a sire genotyped $\mathrm{Mm}$ as a part of combined design in this paper. As a result, all sires from a large grandsire family become informative in combined design consisting of a grandsire, his half-sib sons and granddaughters. Even if the number of sire is one, type 1 error probability was less than $5 \%$ in two cases of 5 and $10 \%$ recombination rates under the condition that family size and the ratio of QTL variance to the total additive genetic variance were 50 and 0.2 , respectively. That would offer a clue for further inspection on microsatellite or candidate gene in the vicinity of the marker site.

Despite of the same total number of sires, the size of type 1 error probability in granddaughter design with 2 grandsires was smaller than that with 1 grandsire. That would be due to the separation of QTL effect and sire's additive genetic effect might be properly conducted in the design with 2 grandsires compared to that with 1 grandsire by reducing average relationship coefficient of sires. Linkage equilibrium of the marker locus, the marked QTL and loci for polygenes are assumed in the generation of grandsire and grandam in this paper. That is, one QTL which has not been selected is considered here. However, if the QTL itself has been under selection, covariance of the marked QTL and loci for polygenes would not be zero. In some cases, gametic disequilibrium would be induced by selection. Thus, accounting for covariance would improve QTL detection when a QTL which has been under selection is considered.

Background genetic noise attributable to other QTL can be reduced by extending the linear regression to multiple regression of 
linked markers ${ }^{19)}$. Thus far, little attention has been paid to the use of flanking markers. The proposed procedure can be extended to the use of flanking markers treating the expected number of the alternative QTL alleles based on the flanking markers as a covariate. This would help to estimate the expected number of the alternative QTL alleles even more accurately.

Regression coefficient in this paper corresponds to the average effect of the gene substitution under no dominance irrespective of gene frequency of the QTL allele. On the other hand, $F$ values to test the significance of the coefficient would become smaller in loose linkage of marker locus and marked QTL than in tight linkage even if the same amount of gene effect or regression coefficient. Therefore, location of one QTL would be masked in a case of loose linkage. That means that markers should be spaced more closely in a targeted part of the genome.

The accuracy of the estimate of QTL effects and of their site increases substantially when more generations with possible recombinations are included in the analysis ${ }^{1,13)}$. On the other hand, genotyping animals is costly and time-consuming work. Analysis by BLUP of sire model with a covariate of expected number of alternative QTL alleles in combined design would pave a way for initial glance for further detailed QTL deliberation. For example, an area with low degree of type 1 error probability would offer a clue to further inspection of candidate gene or microsatellite. Further, in this paper, QTL effect is adopted in a unit of individual not gamate, which would make error variance smaller.

Georges et al. ${ }^{3)}$, Ron et al. ${ }^{14)}$, Vilkki et al. ${ }^{17)}$ and Spelman et al. ${ }^{15)}$ suggested the presence of QTL which have high connection with milkyield traits under the ongoing progeny testing programming with high selection intensity. That would suggest that a certain marker allele co-segregate with a favorable QTL allele in one grandsire family and with an unfavorable QTL allele in a different family. Thus, generation of grandsire and grandam can be treated as a base population in which markers and the QTL are in linkage equilibrium and in which the QTL alleles are present at an initial frequency of 0.5. Sire's mates are randomly chosen under the ongoing progeny testing, which would mean that frequency of the QTL allele in the stage of dam is almost the same as the stage of grandam.

Environmental effects in daughter's record are not considered here. However, preadjustment for these effects of calving year, season and dam's age would be conducted by nationwide preadjustment factors in ongoing progeny testing.

\section{Acknowledgements}

The authors are grateful to anony mous referees for their constructive comments.

\section{References}

1) Davvasi A, Soller M. Advanced intercross lines, an experimental population for fine genetic mapping. Genetics, 141 : 1199-1207. 1995.

2) Falconer DS, Mackay TFC. Introduction to quantitative genetics. $4^{\text {th }}$ ed. 114. Longman Inc. New York. 1996.

3) Georges M, Nielsen D, Mackinnon M, Mishra A, Okimoto R, Pasquino AT, Sargeant LS, Sorensen A, Steele MR, Zhao X, Womack JE, Hoeschele I. Mapping quantitative trait loci controlling milk production in dairy cattle by exploiting progeny testing. Genetics, $139: 907-$ 920. 1995.

4) Guo SW, Thompson EA. Monte carlo estimation of mixed models for large complex pedigrees. Biometrics, 50 : 417-432. 1994.

5) Halley CS, Knott A. A simple regression method for mapping quantitative trait loci in line crosses using flanking markers. Heredity, $69: 315-324.1992$.

6) Halley CS, Knott A, Elsen J-M. Mapping quantitative trait loci in crosses between outbred lines using least squares. Genetics, $136: 1195-$ 1207. 1994.

7) Henderson $C R$. Sire evaluation and genetic trends. In : Animal Breeding and Genetics 


\section{QTL Detection in a Paternal Half-sib Family}

Symposium in Honor of Dr. Jay L. Lush. American Society of Animal Science and American Dairy Science Association. Champaign, IL. 1041. 1973.

8) Hoffer A, Kennedy BW. Genetic evaluation for a quantitative trait controlled by polygenes and a major locus with genotypes not or only partly known. Genet. Sel. Evol., 25 : 537-555. 1993.

9) Janss LLG, Thompson R, van Arendonk JAM. Application of Gibbs sampling for inference in a mixed major gene-polygenic inheritance model in animal populations. Theor. Appl. Genet., 91 : 1137-1147. 1995.

10) Kinghorn BP, Kennedy BW, Smith C. A method of screening for genes of major effect. Genetics, $134: 351-360.1993$.

11) Knott SA, Elsen J-M , Haley CS. Multiple marker mapping of quantitative trait loci in half-sib populations. Proceedings of the $5^{\text {th }}$ World Congress on Genetics Applied to Livestock Production, 33-36. 1994.

12) Meuwissen THE, Goddard ME. Estimation of effects of quantitative trait loci in large complex pedigrees. Genetics, $146:$ 409-416. 1997.

13) Mukai F, Nurimoto M. Efliciency of markerassisted selection on quantitative traits. Anim. Sci. Technol. (Jpn.), $67:$ 181-187. 1996.
14) Ron M, Band M, Yanai A, Weller JI. Mapping quantitative trait loci with DNA microsatellites in a commercial dairy cattle population. Animal Genetics, 25 : 259-264. 1994.

15) Spelman RJ, Coppieters W, Karim L, van Arendonk JAM, Bovenhuis $H$. Quantitative trait loci analysis for five milk production traits on chromosome six in the Dutch Holstein-Friesian population. Genetics, 144 : 1799-1808. 1996.

16) Togashi K, Yamamoto N, Sasaki O. Effects of number of genetic marker alleles, marker interval, degree of substitution effect and paternal half-sib family size on type 1 error probability in the test of the presence of a QTL. Anim. Sci. Technol. (Jpn.), 68:911-916. 1997.

17) Vilkki HJ, de Koning D-J, Elo K, Velmala R, Maki-Tanila A. Multiple marker mapping of quantitative trait loci of finish dairy cattle by regression. J. Dairy Sci., 80:198-204. 1997.

18) Weller JI, Kashi $Y$, Soller M. Power of daughter and granddaughter designs for determining linkage between marker loci and quantitative trait loci in dairy cattle. J. Dairy Sci., 73 : 2525-2537. 1990.

19) Zeng ZB. Precision mapping of quantitative trait loci. Genetics, $136:$ 1457-1468. 1994. 


\title{
対立遺伝子数 2 のシングルマーカーによる父方半きょうだい家系 での量的形質遺伝子座探索
}

\author{
富樫研治・吉臭 努 $^{1)} \cdot$ 菲沢圭二郎 ${ }^{1)} \cdot$ 三橋忠由 $^{1 *}$ * \\ 山本直幸・佐々木 修 \\ 農林水産省北海道農業試験場，札幌市豊平区 062-8555 \\ 1) 農林水産省家畜改良センター，福島県西郷村 961-8061
}

後代検定下の乳牛集団で，大家系を得やすい検定済み種雄牛をベースにして 3 世代にわたり対立遺伝 子数 2 の $\mathrm{M}$ と $\mathrm{m}$ をつ DNA シングルマーカーの分離加ら量的形質遺伝子座（QTL）を探索する方法 を検討した，すなわち，DNA マーカーは，検定風み種雄牛，その半きょうだい息牛，その孫娘牛と 3 世 代にわたり得られるとした，一方，そのDNA マーカーと関連がある乳生産性記録は孫娘牛で得られる とした．孫娘牛の乳生産性記録に対するモデルは，量的形質遗伝子座における対立連伝子期待数を共変 量とした回帰部分とそのQTLに連関していない父牛相加的䝵伝効果の和を遙伝的効果としたサイアー モデルとした．従来のドーターデザイン，グランドドーターデザインに㧍けるマーカーは，前者では父 牛とその娘牛，後者では祖父牛と息牛之別々に得られると定義されているが，ここではマーカーが 3世代にわたって得られることより，本デザインを組み合わせデザインとした．従来のグランドドー ターデザインでは，その息牛であるサイアーのシングルマーカーが $\mathrm{Mm}$ の場合は，グランドサイアー由 来 QTL 遺伝子を推定できなかったが，組み合わせデザインでは Mm のサイアーからその娘牛のマー カーをとることによって孫娘牛記録にしめる QTL 対立道伝子数の推定を可能にした，サイアーのQTL とマーカーとの連鎖相の推定も前世代のマーカーをとることによって改良されると考えられた，父方半 きょうだい家系において QTLが存在するか否加という回熳保数が 0 加否かの検定尺度として第 1 種の 過誤の確率孝もって組み合わ甘（サイアーのマーカー型：Mm, Mm, mm), ドーター (Mm), グラン ドドーターデザイン (MM, mm) を比較した。そその結果, 組み合わせデザインの第 1 種の過誤の確率が 最む少ない傾向を示した．また，グランドサイアーが 1 頭です組換元率 $5,10 \%$ ，サイアー当たり娘牛数 50 頭，全相加的遣伝分散にしめる QTL 分散が 0.2 の場合は，QTL 険定の第 1 種の過誤の確率は $5 \%$ を 下回った，検定済み種雄牛の家系を利用した本法は，統計的手法が容易であり，過䛊の確率が低い染色 体部位近辺住他のマーカーや候補遣伝子探索の糸口を与元ることより, 本法は乳牛集団全体を対象とし たQTL マッピングの予借的手法として意義あるものと考えられた。

日畜会報，69(10)：903-910，1988

*見所属：農林水産省畜産試験場，茨城県筑波農林研究団地 305-0901 